\title{
Impact Dipping Pyramidal-Prismatic Piles and their Resistance to Pressure and Horizontal Load
}

\author{
Isabai Bekbasarov ${ }^{1}$, Nurzhan Shanshabayev ${ }^{2 *}$ \\ ${ }^{1}$ Geotechnical Testing Laboratory, Dulaty University, 60, Tole bi, 080000, Taraz, Kazakhstan \\ ${ }^{2}$ Department of Water Resources and Hydraulic Structures, Faculty of Water Management and Construction, Dulaty University, \\ Campus 6.2, 28, Satpayev, 080012, Taraz, Kazakhstan \\ * Corresponding author, e-mail: nucho91@mail.ru
}

Received: 25 January 2021, Accepted: 31 March 2021, Published online: 19 April 2021

\begin{abstract}
The results of experiments carried out in the field with the use of large-scale models of reinforced concrete driven pyramidal - prismatic piles with different lengths of the pyramidal part are presented. The impact capacity of piles were evaluated of their bearing capacity to the action of indentation and horizontal static loads. It has been established that the driving of pyramidal-prismatic piles is accompanied by both large (by 1.10-1.60 times) and lower (by 8.0-37.0 \%) energy consumption for their driving in comparison with conventional prismatic and pyramidal piles. It was also revealed that under the action of a vertical indentation load, the bearing capacity of the pyramidalprismatic piles is 1.09-1.48 times, and under the action of a horizontal static load, it is 1.17-1.80 times higher than that of a prismatic pile. It has been established that with an increase in the length of the pyramidal part of the test piles, there is an increase in their bearing capacity by 1.12-1.34 times. Formulas are proposed for determining the bearing capacity of pyramidal-prismatic piles. The research results serve as the basis for the development of recommendations for the calculation and design of pyramidal-prismatic piles.
\end{abstract}

\section{Keywords}

model, pyramidal - prismatic pile, soil, driving, testing, load, settlement, bearing capacity

\section{Introduction}

As it is known, prismatic and pyramidal piles are widely used in the practice of pile foundation construction. Prismatic piles, as a rule, are some what inferior in bearing capacity to pyramidal piles. So the bearing capacity of pyramidal piles, depending on the angle of inclination of their lateral faces, is $1.35-2.5$ times higher than the bearing capacity of prismatic piles [1]. But the energy consumption of piling hammers for driving pyramidal piles is 2-3 times higher than for prismatic piles, which is accompanied by a decrease in the productivity of hammers and an increase in the duration of driving pyramidal piles [2]. Consequently, the prismatic piles, yielding to the pyramidal piles in terms of bearing capacity, have significant advantages over them in terms of energy consumption and driving time. As it can be seen, the indicated differences in the behavior of the considered piles are due to their different shape of the longitudinal section.

Based on this, it is obvious that it is relevant to create a pile structure of such a form that would have the advantageous properties of both prismatic and pyramidal piles in an optimal combination [3-7]. Such driven piles include pyramidal-prismatic piles developed in the geotechnical laboratory of M. Kh. Dulaty Taraz Regional University under the support of hydraulic structures [8]. These new pile structures have a combined (pyramidal - prismatic) shape, including both pyramidal (upper) and prismatic (lower) parts. Taking into account the novelty of the proposed piles, the authors carry out complex experimental and theoretical studies to study the features of their driving and work under load.

The results of the preliminary calculation performed earlier, presented in $[9,10]$, show that the shape of the pyramidal-prismatic piles (hereinafter referred to PPP) affects their bearing capacity, which is significantly different from the bearing capacity of pyramidal and prismatic piles.

In the framework of experimental studies at the initial stage, the authors carried out experiments using smallscale models of PPP in a soil flume (in laboratory conditions), the results of which are presented in [11, 12]. 
The purpose of the work is to assess the energy intensity of driving (submersion) of pyramidal-prismatic piles, as well as their resistance to indentation and horizontal loads using large-scale models in the field.

\section{Characteristics of pile models, equipment, and research methods}

Models of piles are made of solid one-piece reinforced concrete with tension-free longitudinal reinforcement and transverse reinforcement of the shaft. The scale of models (hereinafter referred to as piles) is taken as 1:3. Experimental piles were made with a pyramidal section from $33 \mathrm{~cm}$ to $133.2 \mathrm{~cm}$ long (Fig. 1). To compare the research results, three models were adopted as control piles: a prismatic pile with a crosssectional size of $6.7 \times 6.7 \mathrm{~cm}$, a prismatic pile with a crosssectional size of $10.0 \times 10.0 \mathrm{~cm}$, and a pyramidal pile with a cross-sectional size in the upper parts $10.0 \times 10.0 \mathrm{~cm}$ and in the lower part $-6.7 \times 6.7 \mathrm{~cm}$. The slope of the side faces of the pyramidal pile to the vertical was $i_{p}=0.01$. Geometrical parameters and weight of piles are shown in Table 1.

Field tests were carried out at the test site of the production base of the South Kazakhstan branch of "Kazakh Research and Design Institute of Construction and Architecture" JSC. The experimental site, with dimensions in plan $6.0 \times 3.0 \mathrm{~m}$ and a depth of $3.0 \mathrm{~m}$. was composed of sandy loam. Site preparation was included layer-by-layer
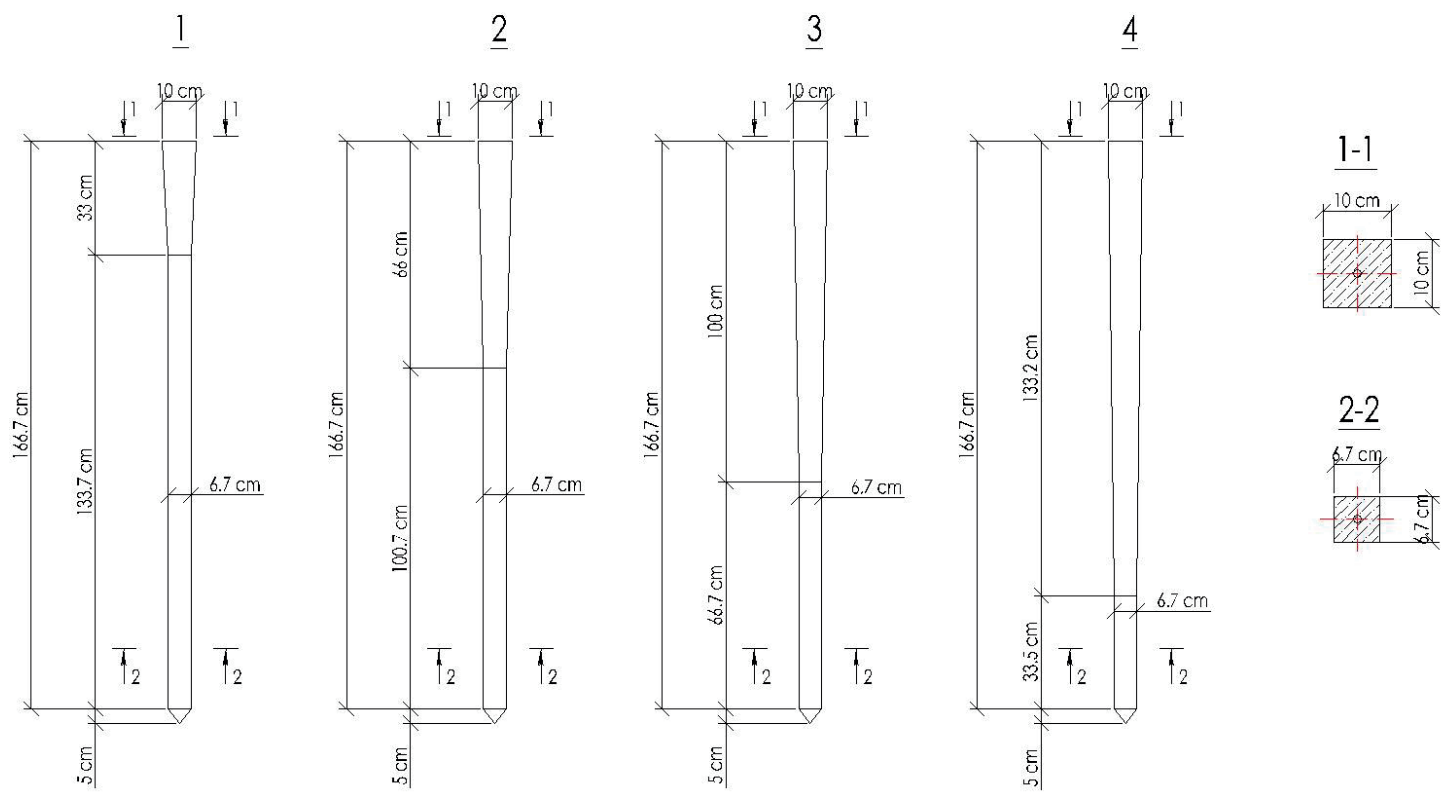

1 - model of PPP with cross-sectional dimensions on top of $10 \times 10 \mathrm{~cm}$ and a pyramidal section $0.2 \mathrm{~L}$ length; 2 - model of PPP with cross-sectional dimensions on top of $10 \times 10 \mathrm{~cm}$ and a pyramidal section $0.4 \mathrm{~L}$ length; 3 - model of PPP with cross-sectional dimensions on top of $10 \times 10 \mathrm{~cm}$ and a pyramidal section $0.6 \mathrm{~L}$ length; 4 - model of PPP with cross-sectional dimensions on top of $10 \times 10 \mathrm{~cm}$ and a pyramidal section $0.8 \mathrm{~L}$ length

Fig. 1 Diagram of pile models

Table 1 Geometric parameters of pile models and their mass

\begin{tabular}{|c|c|c|c|}
\hline \multirow{2}{*}{ Pile type } & \multicolumn{2}{|c|}{ Geometric parameters, $\mathrm{cm}$} & \multirow[t]{2}{*}{ Pile weight, $\mathrm{N}$} \\
\hline & barrel length (spikes) & barrel cross-sectional dimensions & \\
\hline \multicolumn{4}{|l|}{ Experienced piles: } \\
\hline $\begin{array}{l}\text { PPP } 1 \text { (with cross-sectional dimensions on top } 10.0 \times 10.0 \mathrm{~cm} \text { and a } \\
\text { pyramidal part } 0.2 \mathrm{~L} \text { long); }\end{array}$ & \multirow{4}{*}{$\begin{array}{l}166.7 \\
(5.0)\end{array}$} & \multirow{4}{*}{$6.7 \times 6.7$} & 198.1 \\
\hline PPP 2 (also, with a pyramidal part of $0.4 \mathrm{~L}$ length); & & & 212.7 \\
\hline PPP 3 (also, with a pyramidal part of $0.6 \mathrm{~L}$ length); & & & 226.3 \\
\hline PPP 4 (also, with a pyramidal part of $0.8 \mathrm{~L}$ length). & & & 241.1 \\
\hline \multicolumn{4}{|l|}{ Control piles: } \\
\hline prismatic; & \multirow{3}{*}{$\begin{array}{l}166.7 \\
(5.0)\end{array}$} & $6.7 \times 6.7$ & 180.50 \\
\hline prismatic; & & $10.0 \times 10.0$ & 386.51 \\
\hline pyramidal & & $10.0 \times 10.0 / 6.7 \times 6.7$ & 258.0 \\
\hline
\end{tabular}

Note: 1 - Before the line, the cross-sectional dimensions are indicated in the upper part, after the line - in the lower part; 2 - L is the length of the piles without the tip 
laying and uniform compaction of soil from the bottom of a previously dug excavation. The physical and mechanical characteristics of the soil were established by the penetration method using the PSG MG-4 device (Table 2).

Special experimental equipment was developed and manufactured for driving and testing of pile models (Fig. 2). Parameters, principles, and sequence of using this equipment are presented in [13].

The piles were driven into the ground by driving them at a constant energy of each impact. A striker weighing $40 \mathrm{~kg}$ was dropped from a height of $0.5 \mathrm{~m}$. The pile depth was $145.0-145.5 \mathrm{~cm}$ (the maximum difference was $0.34 \%$ ).

Tests of pile models to assess their bearing capacity were carried out in accordance with the requirements of GOST 5686-2012. "Soils. Methods of field testing with piles" [14] by stepwise increasing loading of piles with an indentation static load with the provision of the required conditional stabilization of their settlement. Power loading of each pile was carried out to a settlement of at least 40 $\mathrm{mm}$. The bearing capacity of the piles was determined in accordance with the requirements of SP RK 5.01-103-2013 "Pile foundations" [15].

\section{Research results}

Information is about the number of blows to piles, the energy consumption of the striker for driving them, as well as the depth and volume of the submerged part of the piles are presented in Table 3 . The pile driving records are shown in Fig. 3.

The assessment of the submersion and energy intensity of the pilot and control models of piles based on field tests was carried out on the basis of the following indicators:

- the number of strikes of the striker, spent on driving the pile model (Table 3);

Table 2 Physical and mechanical characteristics of the experimental site soil

\begin{tabular}{lc}
\hline Characteristics & The values \\
\hline Humidity, $\mathrm{W}, \%$ & $3.16-5.58$ \\
Density, $\rho, \mathrm{kg} / \mathrm{m}^{3}$ & $1400-1670$ \\
Moisture at the pour point, $W_{m}, \%$ & $24.18-24.37$ \\
Moisture at the rolling edge, $W_{p}, \%$ & $17.30-17.47$ \\
Plasticity number, $I_{p}$ & $6.88-6.90$ \\
Maximum penetration resistance, $P_{\max }, \mathrm{MPa}$ & $1.47-1.62$ \\
Compaction factor, $K$ & $0.89-0.94$ \\
Index (degree) of humidity, $I$ & $0.75-0.84$ \\
Deformation modulus, $E, \mathrm{MPa}$ & $31.6-33.6$ \\
Internal friction angle, $\varphi$, grade & $17.1-17.6$ \\
Specific adhesion, $c, \mathrm{MPa}$ & $0.018-0.019$ \\
\hline
\end{tabular}

- specific energy consumption of driving the pile model Ev, taken as the ratio of the total potential energy of the striker's impacts spent on driving the model to the volume of its submerged part in the ground (Table 3);

- the coefficient of the relative energy intensity of driving the pile model $K_{e}$, taken as the ratio of the total potential energy of strikes of the striker spent on driving the experimental model of the pile to the same energy parameter of the control model of the pile (Table 4).

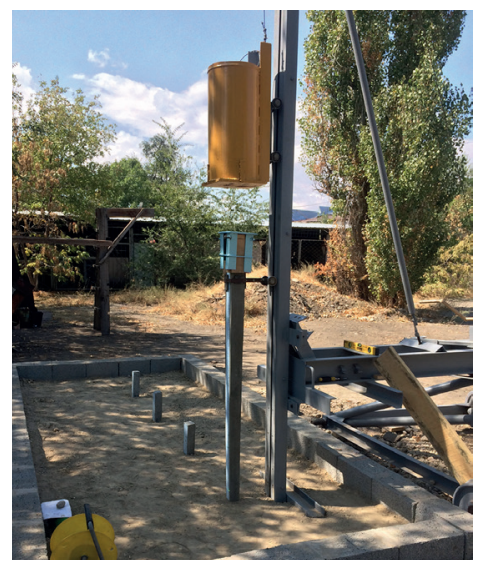

(a)

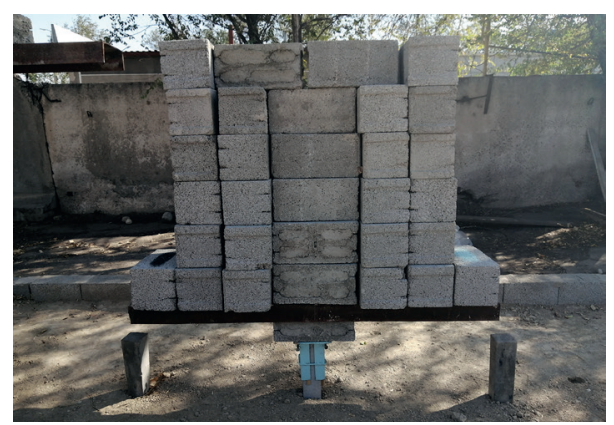

(b)

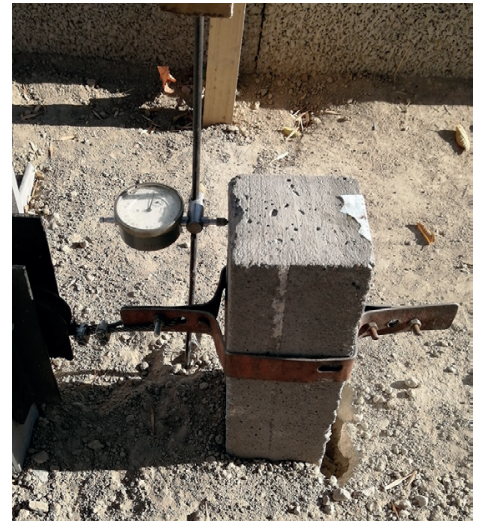

(c)

Fig. 2 Fragments of pile driving (a) and their tests for pressing (b) and horizontal (c) loads 
Table 3 Results of pile models driving

\begin{tabular}{|c|c|c|c|c|}
\hline Pile type & $\begin{array}{l}\text { The total energy of impacts } \\
\text { spent on the hammering } E \text {, } \\
\mathrm{J} \text { (number of strokes) }\end{array}$ & $\begin{array}{l}\text { Immersion depth } \\
\qquad L, \mathrm{~cm}\end{array}$ & $\begin{array}{c}\text { Submerged } \\
\text { volume } V, \mathrm{~cm}^{3}\end{array}$ & $\begin{array}{c}\text { Specific energy } \\
\text { consumption of driving } \\
E_{v}, \mathrm{~J} / \mathrm{cm}^{3}\end{array}$ \\
\hline \multicolumn{5}{|l|}{ Experienced piles: } \\
\hline $\begin{array}{l}\text { PPP } 1 \text { (cross-sectional dimensions on top } 10.0 \times \\
10.0 \mathrm{~cm} \text { and a pyramidal part } 0.2 \mathrm{~L} \text { long) }\end{array}$ & $9914.4(54)$ & 145.5 & 8367.2 & 1.18 \\
\hline PPP 2 (also, with a pyramidal part of $0.4 \mathrm{~L}$ length) & $11016.0(60)$ & 145.4 & 9263.8 & 1.20 \\
\hline PPP 3 (also, with a pyramidal part of $0.6 \mathrm{~L}$ length) & $12301.2(67)$ & 145.0 & 9494.69 & 1.29 \\
\hline PPS 4 (also, with a pyramidal part $0.8 \mathrm{~L}$ long) & $14320.8(78)$ & 145.0 & 10267.3 & 1.40 \\
\hline \multicolumn{5}{|l|}{ Control piles: } \\
\hline Prismatic pile with section dimensions $6.7 \times 6.7 \mathrm{~cm}$ & $8996.4(49)$ & 145.2 & 6592.83 & 1.36 \\
\hline $\begin{array}{l}\text { Prismatic pile with section dimensions } \\
10.0 \times 10.0 \mathrm{~cm}\end{array}$ & $15606.0(85)$ & 145.0 & 14666.6 & 1.06 \\
\hline $\begin{array}{l}\text { Pyramidal pile with cross-sectional dimensions } \\
\text { in the upper part } 10.0 \times 10.0 \mathrm{~cm} \text {, in the lower part } \\
6.7 \times 6.7 \mathrm{~cm}\end{array}$ & $16891.2(92)$ & 145.0 & 9947.8 & 1.70 \\
\hline
\end{tabular}

Note: L - length of piles without tip

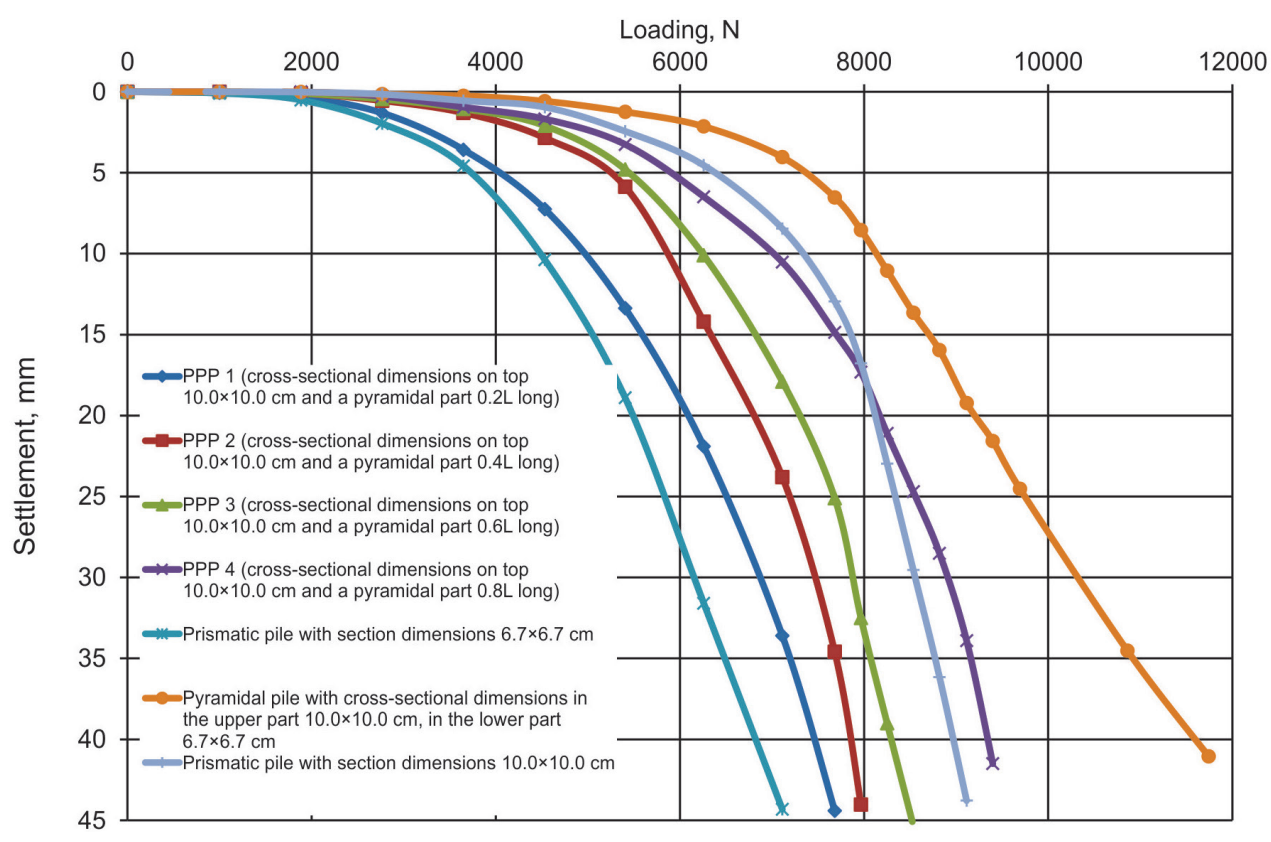

Fig. 3 Pile driving records

Table 4 Coefficient values of the relative energy consumption of driving $K_{e}$ of pile models

\begin{tabular}{lcccc}
\hline $\begin{array}{l}\text { Coefficients of relative } \\
\text { power consumption of } \\
\text { plugging }\end{array}$ & \multicolumn{4}{c}{$\begin{array}{c}\text { Coefficient values for experimental } \\
\text { models of piles with the length of the } \\
\text { pyramidal section }\end{array}$} \\
\hline$K_{e 1}$ & $0,2 \mathrm{~L}$ & $0,4 \mathrm{~L}$ & $0,6 \mathrm{~L}$ & $0,8 \mathrm{~L}$ \\
$K_{e 2}$ & 1.10 & 1.24 & 1.37 & 1.60 \\
$K_{e 3}$ & 0.63 & 0.70 & 0.79 & 0.92 \\
\hline
\end{tabular}

Note: Coefficients, $K_{e 1}, K_{e 2}$ and $K_{e 3}$ respectively refer to models of a prismatic pile with a cross-sectional area of $6.7 \times 6.7 \mathrm{~cm}$, a prismatic pile with a cross-sectional area of $10.0 \times 10.0 \mathrm{~cm}$ and a pyramidal pile with a cross-sectional area of $10.0 \times 10.0 \mathrm{~cm}$ above and below $6.7 \times 6.7 \mathrm{~cm}$
The research results allow us to highlight the following features of the process of driving test piles:

- depending on the length of the pyramidal part of the PPP, with the same immersion depth, the experimental piles compared to prismatic and pyramidal piles can have both large (1.10-1.60 times) and smaller (8.0-37.0 \%) energy consumption for driving;

- energy consumption for immersion of $1 \mathrm{~m}^{3}$ of PPP is 1.03-1.32 times more and 5.43-44.07 \% less than for prismatic and pyramidal piles;

- with an increase in the length of the pyramidal part of the PPP, the energy costs for driving them to the same depth increase by 1.16-1.44 times. 
The results of field tests of piles are presents under the action of a vertical static load in Tables 5-7. Graphs of the dependence of the settlement of pile models on the vertical load are shown in Fig. 4.

A comparative assessment of the resistance of pile models to the action of an indentation load was carried out on the basis of the following indicators:

- bearing capacity $F_{d}$, determined by the formula, taking into account the requirements of SP RK 5.01103-2013 "Pile foundations" (Table 5):

$F_{d}=\gamma_{c} \frac{F_{u, n}}{\gamma_{g}}$,

where: $\gamma_{c}$ - the coefficient of pile working conditions, taken equal to 1,$0 ; F_{u, n}$ - the standard value of the ultimate resistance of the pile, taken equal to its smallest ultimate resistance according to the test results; $\gamma_{g}$ - the soil safety factor, taken equal to 1,0 .

- the characteristic value of the soil resistance to compression in the ultimate state in terms of bearing capacity $R_{c, k}$, determined by the formula in accordance with the requirements of SP RK EN 19971:2004/2011 [16]:

$R_{c ; k}=\frac{\left(R_{c ; m}\right)_{\min }}{\xi_{2}}$,

where: $\left(R_{c ; m}\right)_{\min }-$ the smallest value of the measured value of the soil compressive resistance depending on the number of tests of pile models; $\xi_{2}-$ a correction factor for evaluating the results of testing pile models with a static load, taken equal to 1.40 (for $n=1$ ); $\mathrm{n}$ is the number of tests of pile models;

- specific bearing capacity $F_{d}{ }^{v}$, taken as the ratio of the bearing capacity of the pile to the volume of its

submerged part in the ground (Table 5);

- the coefficient of the relative efficiency of the pile model in terms of bearing capacity $K_{H}$ (by the characteristic value of soil compression resistance $K_{x}$ ), taken in the form of the ratio of the bearing capacity (characteristic value of the soil compressive resistance) of the experimental pile model to the similar force parameter of the control pile model.

The results of static tests of piles make it possible to establish the following features of the operation of experimental piles (at the same settlements):

- in comparison with a prismatic pile with a cross-sectional area of $6.7 \times 6.7 \mathrm{~cm}$, PPP have a higher bearing capacity (1.09-1.48 times);

- in comparison with a prismatic pile with a crosssectional size of $10.0 \times 10.0 \mathrm{~cm}$, PPP with a pyramidal section length of $0.2 \mathrm{~L}-0.6 \mathrm{~L}$ have less (by $8.0-$ $25.0 \%$ ), and PPP with a pyramidal section length 0.8 $\mathrm{L}$ - greater (1.04 times) bearing capacity;

- compared to a pyramidal pile (with dimensions at the top $10.0 \times 10.0 \mathrm{~cm}$ and at the bottom $-6.7 \times 6.7 \mathrm{~cm}$ ), PPP have a lower (by 20.0-36.0\%) bearing capacity;

Table 5 Bearing values $F_{d}$ and specific bearing capacity $F_{d}{ }^{v}$ piles, as well as the characteristic value of the soil compression resistance $R_{c, k}$

\begin{tabular}{|c|c|c|c|c|c|c|}
\hline \multirow[t]{2}{*}{ Pile type } & \multicolumn{2}{|c|}{$\begin{array}{c}\text { Pile bearing capacity } F_{d}, \mathrm{~N} \text {, at } \\
\text { settlement }\end{array}$} & \multicolumn{2}{|c|}{$\begin{array}{l}\text { Specific bearing capacity of the } \\
\text { pile } F_{d}^{v}, \mathrm{~N} / \mathrm{cm}^{3} \text {, at settlement }\end{array}$} & \multicolumn{2}{|c|}{$\begin{array}{c}\text { Characteristic value of soil } \\
\text { compression resistance } R_{c, k}, \mathrm{~N} \text {, at } \\
\text { settlement }\end{array}$} \\
\hline & $20 \mathrm{~mm}$ & $40 \mathrm{~mm}$ & $20 \mathrm{~mm}$ & $40 \mathrm{~mm}$ & $20 \mathrm{~mm}$ & $40 \mathrm{~mm}$ \\
\hline Experienced piles: & 6100 & 7470 & 0.73 & 0.89 & 4357.14 & 5335.71 \\
\hline \multicolumn{7}{|l|}{$\begin{array}{l}\text { PPP } 1 \text { (with cross-sectional } \\
\text { dimensions on top } 10.0 \times 10.0 \mathrm{~cm} \text { and } \\
\text { a pyramidal part } 0.2 \mathrm{~L} \text { long) }\end{array}$} \\
\hline $\begin{array}{l}\text { PPP } 2 \text { (also, with a pyramidal part of } \\
0.4 \text { L length) }\end{array}$ & 6820 & 7860 & 0.74 & 0.85 & 4871.43 & 5614.28 \\
\hline $\begin{array}{l}\text { PPP } 3 \text { (also, with a pyramidal part of } \\
0.6 \text { L length) }\end{array}$ & 7310 & 8300 & 0.77 & 0.87 & 5221.43 & 5928.57 \\
\hline PPP 4 (also, pyramidal part $0.8 \mathrm{~L}$ long) & 8175 & 9340 & 0.80 & 0.91 & 5839.28 & 6671.48 \\
\hline Control piles: & 5500 & 6825 & 0.83 & 1.03 & 3928.57 & 4875.0 \\
\hline \multicolumn{7}{|l|}{$\begin{array}{l}\text { prismatic with section dimensions } \\
6.7 \times 6.7 \mathrm{~cm}\end{array}$} \\
\hline $\begin{array}{l}\text { prismatic pile with section dimensions } \\
10.0 \times 10.0 \mathrm{~cm}\end{array}$ & 8125 & 8975 & 0.55 & 0.61 & 5803.57 & 6410.71 \\
\hline $\begin{array}{l}\text { pyramidal pile with the dimensions of } \\
\text { the upper section } 10.0 \times 10.0 \mathrm{~cm} \text { and } \\
\text { the lower section }-6.7 \times 6.7 \mathrm{~cm}\end{array}$ & 9250 & 11625 & 0.99 & 1.17 & 6607.14 & 8303.57 \\
\hline
\end{tabular}




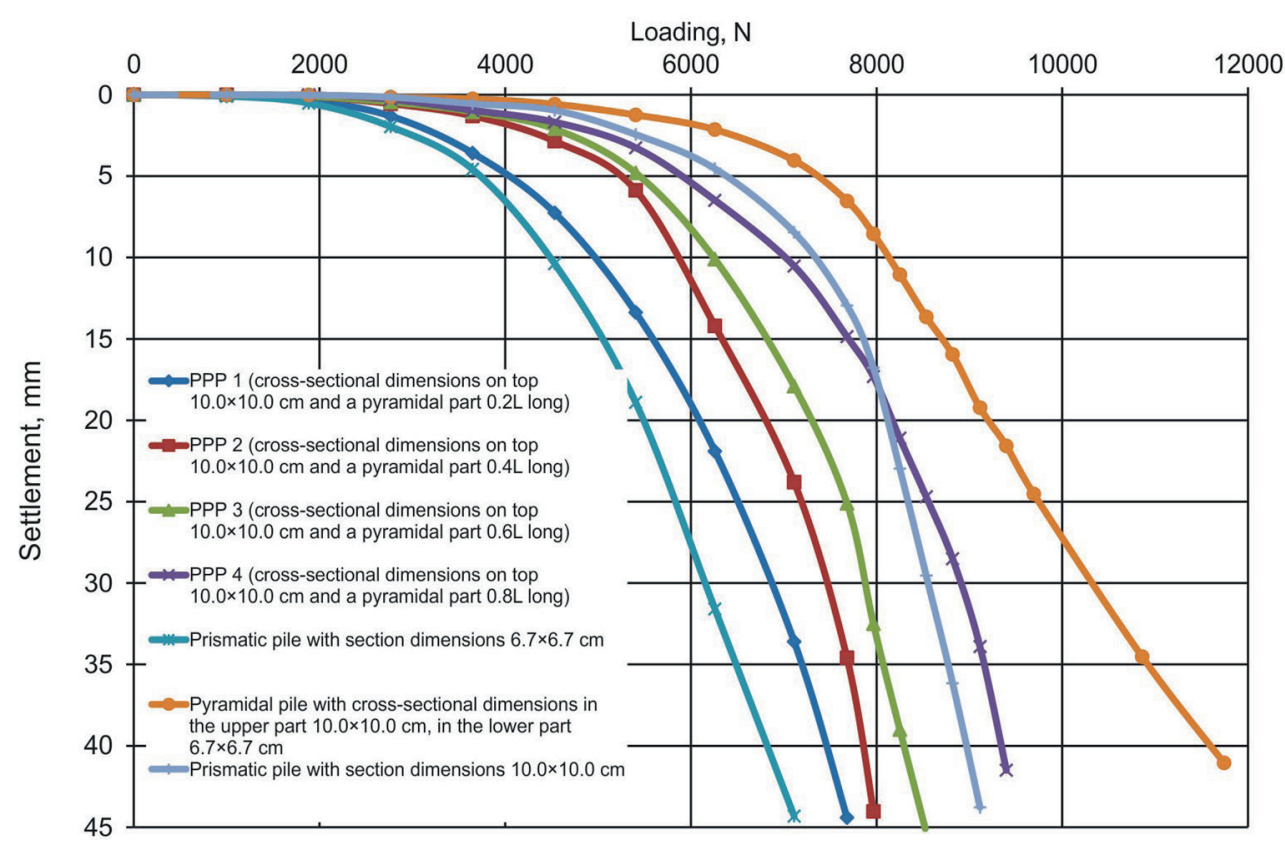

Fig. 4 Dependence of the pile settlement on the pressing static load

Table 6 Coefficient values of the relative efficiency of pile models for bearing capacity $K_{H}$ at pile settlement to $20 \mathrm{~mm}$

\begin{tabular}{lcccc}
\hline $\begin{array}{l}\text { Relative efficiency } \\
\text { coefficients for bearing } \\
\text { capacity of models }\end{array}$ & \multicolumn{4}{c}{$\begin{array}{c}\text { Coefficient values for experimental } \\
\text { models of piles with the length of the } \\
\text { pyramidal part }\end{array}$} \\
\hline$K_{H 1}$ & $0.2 \mathrm{~L}$ & $0.4 \mathrm{~L}$ & $0.6 \mathrm{~L}$ & $0.8 \mathrm{~L}$ \\
$K_{H 2}$ & 1.11 & 1.24 & 1.32 & 1.48 \\
$K_{H 3}$ & 0,75 & 0.84 & 0.90 & 1.0 \\
\hline
\end{tabular}

Note - Coefficients, $K_{H 1}, K_{H 2}$ and $K_{H 3}$ respectively refer to models of a prismatic pile with a cross-sectional area of $6.7 \times 6.7 \mathrm{~cm}$, a prismatic pile with a cross-sectional area of $10.0 \times 10.0 \mathrm{~cm}$ and a pyramidal pile with a cross-sectional area of $10.0 \times 10.0 \mathrm{~cm}$ above and below $6.7 \times 6.7 \mathrm{~cm}$.

- the specific bearing capacity of the test piles is higher than the specific bearing capacity of a prismatic pile with a section size of $10.0 \times 10.0 \mathrm{~cm}$ : with a pile settlement of $20 \mathrm{~mm}-1.33-1.45$ times; with precipitation of $40 \mathrm{~mm}-1.46-1.49$ times;

- with an increase in the length of the pyramidal part, the bearing capacity of the test piles (at the same settlement values) increases by 1.12-1.34 times.

Pile foundations, actually, operate under conditions of combined action of horizontal (moment) and vertical loads $[17,18]$. Therefore, the study of the PPP on the horizontal load is urgent purpose.

The results of testing piles for horizontal loading performed in the field are presented in Tables 8 and 9, as well as in Fig. 5.
Table 7 Coefficient values of the relative efficiency of pile models for bearing capacity $K_{H}$ at pile settlement to $40 \mathrm{~mm}$

\begin{tabular}{lcccc}
\hline $\begin{array}{l}\text { Relative efficiency } \\
\text { coefficients for bearing } \\
\text { capacity of models }\end{array}$ & \multicolumn{4}{c}{$\begin{array}{c}\text { Coefficient values for experimental } \\
\text { models of piles with the length of the } \\
\text { pyramidal part }\end{array}$} \\
\hline$K_{H 1}$ & $0.2 \mathrm{~L}$ & $0.4 \mathrm{~L}$ & $0.6 \mathrm{~L}$ & $0.8 \mathrm{~L}$ \\
$K_{H 2}$ & 1.09 & 1.15 & 1.21 & 1.37 \\
$K_{H 3}$ & 0.83 & 0.87 & 0.92 & 1.04 \\
\hline
\end{tabular}

Note-Coefficients $K_{H 1}, K_{H 2}$ and $K_{H 3}$ respectively refer to models of a prismatic pile with a cross-sectional area of $6.7 \times 6.7 \mathrm{~cm}$, a prismatic pile with a cross-sectional area of $10.0 \times 10.0 \mathrm{~cm}$ and a pyramidal pile with a cross-sectional area of $10.0 \times 10.0 \mathrm{~cm}$ above and below $6.7 \times 6.7 \mathrm{~cm}$

Comparative assessment of the resistance of piles to the action of horizontal (transverse) load was carried out on the basis of the coefficient of relative efficiency of pile models in horizontal displacement $K_{g p}$ (transverse load resistance $K_{t r}$ ).

Coefficient $K_{g p}\left(K_{t r}\right)$ is set as the bearing capacity ratio $F_{d, g p}$ (lateral load resistance $R_{t r}$ ) an experimental model of a pile (with a horizontal movement of $10 \mathrm{~mm}$ of its head) to a similar force parameter of the control model of a pile.

From Tables 8 and 9 , the following patterns of behavior of experimental piles under the action of a horizontal load are follow:

- the bearing capacity of the PPP is $1.17-1.80$ times greater than the bearing capacity of a prismatic pile with a section size of $6.7 \times 6.7 \mathrm{~cm}$; 
Table 8 Bearing values $F_{d g p}$ and lateral load resistance $R_{t r}$ piles with horizontal displacement of their head by $10 \mathrm{~mm}$

\begin{tabular}{|c|c|}
\hline Pile type & $\begin{array}{l}\text { Pile bearing capacity } \\
F_{d, g p} \text { (pile lateral load } \\
\left.\quad \text { resistance } R_{t r}\right), \mathrm{N}\end{array}$ \\
\hline \multicolumn{2}{|l|}{ Experienced piles: } \\
\hline $\begin{array}{l}\text { PPP } 1 \text { (with cross-sectional dimensions on } \\
\text { top } 10.0 \times 10.0 \mathrm{~cm} \text { and a pyramidal part } \\
0.2 \mathrm{~L} \text { long) }\end{array}$ & 2255 \\
\hline $\begin{array}{l}\text { PPP } 2 \text { (also, with a pyramidal part of } 0.4 \\
\text { L length) }\end{array}$ & 2580 \\
\hline $\begin{array}{l}\text { PPP } 3 \text { (also, with a pyramidal part of } 0.6 \\
\text { L length) }\end{array}$ & 2835 \\
\hline $\begin{array}{l}\text { PPP } 4 \text { (also, with a pyramidal part } 0.8 \mathrm{~L} \\
\text { long) }\end{array}$ & 3450 \\
\hline \multicolumn{2}{|l|}{ Control piles: } \\
\hline $\begin{array}{l}\text { prismatic (with cross-sectional } \\
\text { dimensions } 6.7 \times 6.7 \mathrm{~cm} \text { ) }\end{array}$ & 1918 \\
\hline $\begin{array}{l}\text { prismatic (with section dimensions } 10.0 \\
\times 10.0 \mathrm{~cm})\end{array}$ & 4310 \\
\hline $\begin{array}{l}\text { pyramidal (with dimensions of the upper } \\
\text { section } 10.0 \times 10.0 \mathrm{~cm} \text {, the lower section } \\
6.7 \times 6.7 \mathrm{~cm} \text { ) }\end{array}$ & 4030 \\
\hline
\end{tabular}

- the bearing capacity of the PPP is $20.0-48.0 \%$ less than the bearing capacity of a prismatic pile with a section size of $10.0 \times 10.0 \mathrm{~cm}$;

- the bearing capacity of the PPP is 15.0-44.0\% less than the bearing capacity of the pyramidal pile (with the dimensions of the upper section $10.0 \times 10.0 \mathrm{~cm}$ and the lower section $6.7 \times 6.7 \mathrm{~cm})$;
Table 9 The values of the coefficients of the relative efficiency of experimental piles for horizontal displacement $K_{g p 1}$ (transverse load

resistance $K_{t r 1}$ )

\begin{tabular}{lcccc}
\hline Relative efficiency ratios & \multicolumn{4}{c}{$\begin{array}{c}\text { Coefficient values for experimental } \\
\text { models of piles with the length of the } \\
\text { pyramidal part }\end{array}$} \\
\hline$K_{g p 1}\left(K_{t r 1}\right)$ & $0.2 \mathrm{~L}$ & $0.4 \mathrm{~L}$ & $0.6 \mathrm{~L}$ & $0.8 \mathrm{~L}$ \\
$K_{g p 2}\left(K_{t r 2}\right)$ & 1.17 & 1.35 & 1.48 & 1.80 \\
$K_{g p 3}\left(K_{t r 3}\right)$ & 0.52 & 0.60 & 0.65 & 0.80 \\
\hline
\end{tabular}

Note: $K_{g p 1}\left(K_{t r 1}\right), K_{g p 2}\left(K_{t r 2}\right)$ and $K_{g p 3}\left(K_{t r 3}\right)$ - coefficients related to the models of a prismatic pile with a cross-sectional area of $6.7 \times 6.7 \mathrm{~cm}$, a prismatic pile with a cross-sectional area of $10.0 \times 10.0 \mathrm{~cm}$ and a pyramidal pile with a cross-sectional area of $10.0 \times 10.0 \mathrm{~cm}$, and to the bottom $-6.7 \times 6.7 \mathrm{~cm}$

- the bearing capacity of the test piles increases by 1.22-1.53 times with an increase in the length of the pyramidal part from $0.2 \mathrm{~L}$ to $0.8 \mathrm{~L}$.

\section{Calculation formulas}

The data presented in Tables 6 and 7 are mathematically described by the following linear function:

$K_{H}=a l+b$,

where: $K_{H}$ - coefficient of relative efficiency for the bearing capacity of piles;

$l$ - length of the pyramidal part of the PPP; $a$ and $b-$ coefficients taken according to Tables 10 and 11 .

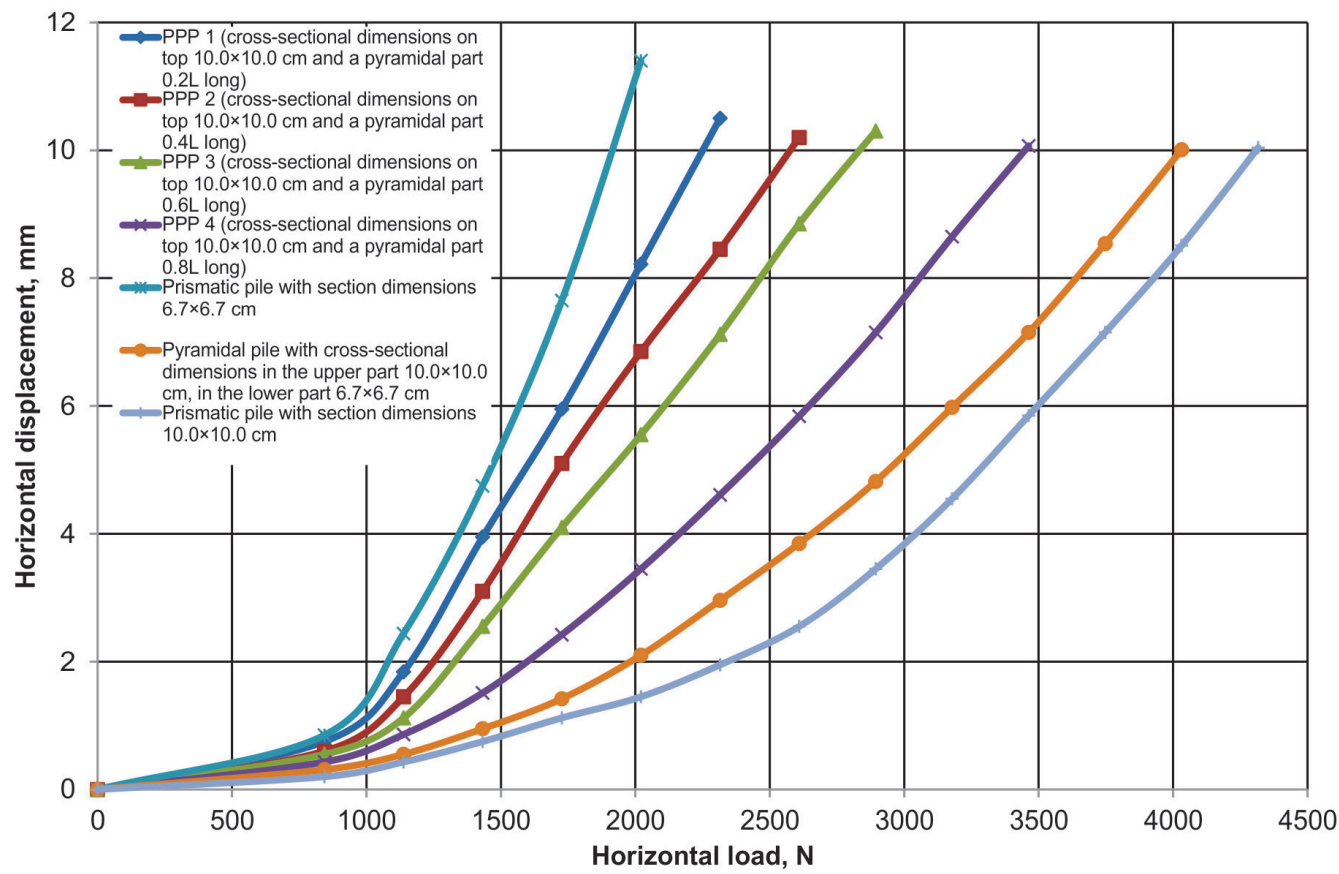

Fig. 5 Dependence of the displacement of the head of the piles on the static horizontal load 
Table 10 Coefficient values of $a$ and $b$ in $K_{H}$ Eq. (3) at pile settlement to $20 \mathrm{~mm}$

\begin{tabular}{lccc}
\hline $\begin{array}{l}\text { Relative efficiency } \\
\text { coefficients for bearing } \\
\text { capacity of piles }\end{array}$ & a & b & $\begin{array}{l}\text { The value of the } \\
\text { accuracy of the } \\
\text { approximation }\left(\mathrm{R}^{2}\right)\end{array}$ \\
\hline$K_{H 1}$ & 0.119 & 0.99 & 0.985 \\
$K_{H 2}$ & 0.081 & 0.67 & 0.991 \\
$K_{H 3}$ & 0.071 & 0.59 & 0.989 \\
\hline
\end{tabular}

Table 11 Coefficient values of $a$ and $b$ in $K_{H}$ Eq. (3) at pile settlement to $40 \mathrm{~mm}$

\begin{tabular}{lccc}
\hline $\begin{array}{l}\text { Relative efficiency } \\
\text { coefficients for bearing } \\
\text { capacity of piles }\end{array}$ & \multicolumn{2}{c}{ Coefficient values } & $\begin{array}{r}\text { The value of the } \\
\text { accuracy of the } \\
\text { approximation }\left(\mathrm{R}^{2}\right)\end{array}$ \\
\hline$K_{H 1}$ & 0.09 & 0.98 & 0.931 \\
$K_{H 2}$ & 0.068 & 0.745 & 0.928 \\
$K_{H 3}$ & 0.052 & 0.575 & 0.932 \\
\hline
\end{tabular}

The data presented in Table 9 are mathematically describes by the following linear function:

$K_{g p}=k l+p$,

where: $l$ - length of the pyramidal section of the PPP; $k$ and $p$ - coefficients taken according to Table 12 .

The test results presented in Table 9 allow obtaining the following correlation dependences:

$$
\begin{aligned}
& F_{\mathrm{PPP}}=F_{g p 1}+\Delta_{F}, \\
& F_{\mathrm{PPP}}=F_{g p 2}-\Delta_{F}, \\
& F=F_{g p 3}-\Delta_{F}, \\
& \Delta_{F}=g l+d,
\end{aligned}
$$

where: $F_{g p 1}, F_{g p 2}, F_{g p 3}$ - bearing capacity, respectively, of the model of a prismatic pile with a cross-sectional area of $6.7 \times 6.7 \mathrm{~mm}$, a model of a prismatic pile with a cross-sectional area of $10 \times 10 \mathrm{~mm}$ and a model of a pyramidal pile with a cross-sectional size in the upper part of $10 \times 10 \mathrm{~mm}$, in the lower part - downward - $6.7 \times 6.7 \mathrm{~mm}, N ; \Delta_{F}$ - difference between the values of the bearing capacity of the test and control piles, $N ; g$ and $d$ - coefficients taken from the Table $13 ; l$ - the length of the pyramidal section of the PPP.

The presented data allow us to draw the following conclusions:

- a calculation formula has been obtained that allows one to determine the experimental data of the relative efficiency coefficients for the bearing capacity of the PPP under the action of a pressing static load;
Table 12 The values of the coefficients $k$ and $p$ in the Eq. (4)

\begin{tabular}{lccc}
\hline $\begin{array}{l}\text { Horizontal relative } \\
\text { efficiency ratios }\end{array}$ & \multicolumn{2}{c}{ Coefficient values } & $\begin{array}{c}\text { The value of the } \\
\text { accuracy of the } \\
\text { approximation }\left(\mathrm{R}^{2}\right)\end{array}$ \\
\hline$K_{g p 1}$ & 0.202 & 0.945 & 0.963 \\
$K_{g p 2}$ & 0.093 & 0.455 & 0.959 \\
$K_{g p 3}$ & 0.089 & 0.42 & 0.950 \\
\hline
\end{tabular}

Table 13 The values of the coefficients $g$ and $d$ in the formula (8)

\begin{tabular}{cccc}
\hline $\begin{array}{c}\text { The quantity } \Delta_{F} \text { in } \\
\text { the formula }\end{array}$ & $g$ & $d$ & $\begin{array}{c}\text { Coefficient values } \\
\text { accuracy of the } \\
\text { approximation }\left(\mathrm{R}^{2}\right)\end{array}$ \\
\hline (5) & 384 & 98 & 0.960 \\
$(6)$ & -384 & 2210 & 0.960 \\
$(7)$ & -384 & 2490 & 0.960 \\
\hline
\end{tabular}

- formulas are proposed for the calculated determination of the bearing capacity of the PPP under the action of a horizontal static load relative to a similar power parameter of the control piles;

- the obtained formulas are distinguished by a fairly high (from 92 to $99 \%$ ) reliability of the calculation results.

\section{Conclusions}

The following main conclusions can be formulated, based on the presented results of experimental studies:

- with an increase in the length of the pyramidal section of the PPP, the energy costs for their immersion increase, and their bearing capacity (specific bearing capacity) also increases under the action of pressing and transverse loads;

- depending on the length of the pyramidal section the PPP, in comparison with prismatic and pyramidal piles, have both greater and lesser bearing capacity (specific bearing capacity);

- for the calculated determination of the bearing capacity of the PPP under the action of a horizontal load, formulas were obtained that ensure high reliability of the calculation results.

Thus, the length of the pyramidal part of the PPP has a significant effect on the energy consumption of their driving, immersion and resistance to the action of an indentation and horizontal load, which it is explained, in our opinion, by effective compaction and a significant manifestation of soil repulsive forces under the inclined edges of the pyramidal part of the PPP when they are introduced into the soil strata. 


\section{Acknowledgements}

The authors grateful to Mr. Baitemirov M., Director of "Kazakh Research and Design Institute of Construction

\section{References}

[1] Bekbasarov, I. I., Isakov, G. I., Amanbai, A. "Assessment of the influence of the parameters of piles and stamps on their immersion and bearing capacity of foundation structures", Taraz University, Taraz, Kazakhstan, 2014. (in Russian)

[2] Medvedeva, O. P., Bulankin, N. F. "Determination of the bearing capacity of pyramidal-prismatic piles based on the results of dynamic tests", In: International Seminar on Soil Mechanics, Foundation Construction and Transport Facilities, Moscow, Russia, 2000, pp. 196-199. (in Russian)

[3] Isaev, V. I., Maltsev, A. V., Karpov, A. A. "Comparative evaluation of bearing capacity of a short driven pyramidal-prismatic pile using mathematical models", Procedia Engineering, 153, pp. 223-227, 2016.

https://doi.org/10.1016/j.proeng.2016.08.106

[4] Kupchikova, N. V., Kurbatskiy, E. N. "Analytical Method Used to Calculate Pile Foundations with the Widening Up on a Horizontal Static Impact", IOP Conference Series: Materials Science and Engineering, 262, Article No. 012102, 2017.

https://doi.org/10.1088/1757-899X/262/1/012102

[5] Atenov, Y., Bekbasarov, I. "Equations Used to Calculate Vertical Bearing Capacity of Driven Piles with Shaft Broadenings", Periodica Polytechnica Civil Engineering, 64(4), pp. 1235-1243, 2020. https://doi.org/10.3311/PPci.16482

[6] Movahedi Rad, M. "Reliability Based Analysis and Optimum Design of Laterally Loaded Piles", Periodica Polytechnica Civil Engineering, 61(3), pp. 491-497, 2017. https://doi.org/10.3311/PPci.8756

[7] Movahedi Rad, M. "A Review of Elasto-Plastic Shakedown Analysis with Limited Plastic Deformations and Displacements", Periodica Polytechnica Civil Engineering, 62(3), pp. 812-817, 2018. https://doi.org/10.3311/PPci.11696

[8] Bekbasarov, I. I., Shanshabaev, N. A. "Driven reinforced concrete pile", Patent for utility model of the Republic of Kazakhstan, National Institute of Intellectual Property, RSE, Nur-Sultan, Kazakhstan, No. 4521, 2019. (in Russian)

[9] Bekbasarov, I. I., Shanshabaev, N. A. "On the calculated assessment of the bearing capacity of driven piles with a pyramidal section of the shaft", In: Central Asia International Scientific Practical Conference IV Global Science and Innovation 2019, Astana, Kazakhstan, 2019, pp. 10-15. [online] (in Russian) and Architecture" SKB of JSC and Mr. Atenov Y., post graduate student of the Dulaty University for their advice and assistance in conducting field tests of pile models.

[10] Bekbasarov, I. I., Shanshabaev, N. A. "On the bearing capacity of the pyramidal-prismatic piles", In: I International Book Edition of the Commonwealth of Independent States "The Best Young Scientist - 2020", Nur-Sultan, Kazakhstan, 2020, pp. 79-83. (in Russian)

[11] Bekbasarov, I. I., Shanshabayev, N. A. "On the energy intensity of driving and the bearing capacity of the models of pyramidal-prismatic piles", Bulletin of the Kazakh Head Architectural and Civil Engineering Academy, 75(1), pp. 97-106, 2020. (in Russian) [online] Available at: http://rmebrk.kz/magazine/1523\#

[12] Bekbasarov, I. I., Shanshabayev, N. A. "On the influence of the size of pyramidal part of the pyramidal-prizmatic piles on their energy consumption and bearing capacity", Vestnik KazNRTU, 136(6), pp. 190-199, 2020. [online] Available at: https://vestnik.satbayev. university/index.php/journal/issue/view/49 (in Russian)

[13] Bekbasarov, I. I., Atenov,Y. I., Shanshabaev, N. A. "On laboratory equipment for driving and testing pile models", Mechanics and Technologies, 66(4), pp. 125-133, 2019. (in Russian)

[14] GOST "GOST 5686-2012 Soils. Field test methods by piles", Federal Agency for Technical Regulation and Metrology, Moscow, Russia, 2014. (in Russian)

[15] Kazakh Research and Design Institute of Construction and Architecture "Code of Practice SP RK 5.01-103-2013 Pile foundations", Ministry of National Economy of the Republic of Kazakhstan, Astana, Kazakhstan, 2015. [online] Available at: https://www.egfntd.kz/rus/page/NTD_KDS_SPRK (in Russian)

[16] "Kazakh Research and Design Institute of Construction and Architecture" JSC SP RK EN 1997-1:2004/2011 Geotechnical design. Part 1. General rules", Construction and HousingCommunal Services Affairs Committee of the Republic of Kazakhstan, Astana 2016. (in Russian)

[17] Movahedi Rad, M. Fehér, Z. "Plastic Limit Analysis of Lateral Piles for Uncertain Conditions", In: Topping, B. H. V., Iványi, P. (eds.) Proceedings of the Twelfth International Conference on Computational Structures Technology, Civil-Comp Press, Stirlingshire, UK, Paper 137, 2014. https://doi.org/10.4203/ccp.106.137

[18] Gotman, A. L., Sokolov, L. Y. "To calculation of the combined piles for horizontal load", Soil Mechanics and Foundation Engineering, 2, pp. 79-90, 2014. [online] Available at: https://ofmg.ru/index. php/ofmg/article/view/5695 